\title{
Idiopathic pulmonary fibrosis: current understanding of the pathogenesis and the status of treatment
}

\author{
Nasreen Khalil, Robert O'Connor
}

Abstract

IDIOPATHIC PULMONARY FIBROSIS (IPF) is a progressive and lethal pulmonary fibrotic lung disease. The diagnostic histological changes are called usual interstitial pneumonia and are characterized by histological temporal heterogeneity, whereby normal lung tissue is interspersed with interstitial fibrosis, honeycomb cysts and fibroblast foci. Pulmonary functions show restricted volumes and capacities, preserved flows and evidence of decreased gas exchange. High-resolution computed axial tomography demonstrates evidence of fibrosis and lung remodelling such as honeycomb cysts and traction bronchiectasis. There is no known effective treatment for IPF, but lung transplantation improves survival.

CMAJ 2004;171(2):153-60

$\mathrm{I}$ diopathic pulmonary fibrosis (IPF) is the most common of the idiopathic interstitial pneumonias and the one that is unresponsive to treatment. ${ }^{1-4}$ The purpose of this review is to help clinicians understand the disease and appropriately investigate suspected cases. IPF, known in Europe as cryptogenic fibrosing alveolitis, is a clinical term that describes a chronic fibrosing interstitial pneumonia with no known cause. ${ }^{1-4}$ In the past the term IPF included a number of idiopathic interstitial pneumonias that, in the revised histological classification, are now considered separate clinicopathogical entities. There are 7 distinct histological groups (see Table 1) with similar clinical presentations, but their clinical courses and responses to therapy differ. ${ }^{4-12}$

\section{Epidemiology}

The incidence and prevalence of IPF have been difficult to determine because until recently the diagnostic criteria were uncertain and the terminology was poorly defined., ${ }^{3,4}$ The General Practice Research Database and the 4th Morbidity Survey in General Practice from the United Kingdom suggest a prevalence of IPF of $1.5-1.8$ per 10000 person-years and an incidence of 0.5 per 10000 personyears. ${ }^{13} \mathrm{IPF}$ is more prevalent than other interstitial pneumonias and is diagnosed more frequently in men (male: female prevalence ratio 1.4:1.0; male:female incidence ratio 1.3:1.0). ${ }^{14} \mathrm{IPF}$ is most commonly seen in patients between the ages of 40 and 70, and the majority of patients are over 60 years of age..$^{3,6-9,11}$ The mean length of survival after diagnosis is $3.2-5$ years. ${ }^{1-9}$

\section{Etiology}

Although the pathogenesis of IPF remains elusive, a number of conditions and risk factors are associated with the disease. Cigarette smoking increases the risk of IPF, with an odds ratio (OR) of 2.3 (confidence interval [CI] 1.3-3.8) among smokers with 20-40 pack-years of smoking. ${ }^{15}$ Several occupational factors, adjusted for age and smoking, are associated with IPF, such as farming (OR 1.6, 95\% CI 1.0-2.5), hairdressing (OR 4.4, 95\% CI 1.2-16.3), stonecutting (OR 3.9, 95\% CI 1.2-12.7), and exposure to livestock (OR 2.7, 95\% CI 1.3-5.5), birds (OR 4.7, 95\% CI 1.6-14.1) and dust from metals (OR 2.0, 95\% CI 1.0-4.0) and vegetables (OR 4.7, 95\% CI 2.1-10.4)..$^{16,17}$ Although viruses have not been clearly implicated in the pathogenesis of IPF, several viral proteins and antibodies to viruses are associated with the disease, such as the Epstein-Barr virus, ${ }^{18}$ influenza A virus,${ }^{19}$ hepatitis $\mathrm{C}$ virus,${ }^{20}$ parainfluenza viruses 1 and $3,{ }^{21} \mathrm{HIV}-1^{21}$ and herpesvirus $6,{ }^{21}$ to name a few. Some people may have a genetic predisposition to IPF, as there have been cases of families in which at least 2 primary members had IPF. ${ }^{22}$ Familial IPF may be inherited as an autosomal dominant trait with variable penetrance, but this speculation has not been supported in each instance. . $23-26^{2}$ Inherited abnormalities in surfactant proteins ${ }^{24}$ and the interleukin-1 (IL-1) receptor antagonist, ${ }^{25}$ as well as polymorphism of the tumour necrosis factor-alpha gene ${ }^{25}$ and complement receptor 1 gene, ${ }^{26}$ have been associated with some cases of IPF, which suggests that obscure biochemical aberrancies can lead to an IPF-like condition. ${ }^{24-26}$

\section{Pathogenesis}

Despite some of these associations, IPF has traditionally been thought to occur as a result of an initial injury to the lung that causes the recruitment of inflammatory cells, release of cytokines and eventually, from increased fibroblast activity, parenchymal remodelling and fibrosis. ${ }^{27-33}$ However, pulmonary fibrosis has been demonstrated in animal models in the absence of inflammatory cells. ${ }^{33,34}$ Furthermore, because inflammatory suppressive agents do not seem to be effective, it may be that IPF is not caused by inflammatory cells but that inflammatory cells are secondarily involved. ${ }^{29-33}$

More recent research has demonstrated that alveolar epithelial cells, as a consequence of injury by an unknown cause, may be the source of a number of fibrogenic cy- 
tokines such as transforming growth factor-beta $1,,^{33-38}$ platelet-derived growth factor, ${ }^{39}$ tumour necrosis factoralpha, ${ }^{40,41} \mathrm{IL}-1,{ }^{40}$ insulin-like growth factor $1^{42}$ and basic fibroblast growth factor. ${ }^{43}$ Release of these cytokines may result in fibroblast proliferation and migration to various sites in the lung, followed by differentiation of the fibroblast phenotype. $^{44,45}$ This differentiation of the fibroblast is likely the key to the chronic nature of IPF. First, the differentiated cell seems to be more resistant to apoptosis (natural cell death), a process that is important in the repair of tissue without excessive scarring ${ }^{45,46}$ second, the altered cells demonstrate a heightened responsiveness to fibrogenic cytokines such as transforming growth factor-beta and basic fibroblast growth factor. ${ }^{45,46}$ These events would lead to prolonged retention of fibroblasts, continued connective tissue protein synthesis and the formation of fibroblast foci, a histological hallmark in IPF. ${ }^{1-4}$

Attempts to elucidate an immunological basis for the pathogenesis of IPF have been made. In brief, it appears that the type $2 \mathrm{~T}$-cell response predominates in IPF, with an increase in IL-4 and IL-13. ${ }^{47}$ Although levels of circulating autoantibodies such as antinuclear antibodies, anti-DNA antibodies, anti-cytokeratin 8 antibodies and immune complexes may be elevated, ${ }^{48}$ the significance of these abnormalities is unclear. In summary, although the histological features of IPF suggest an inflammatory or immunologic cause, no distinct pathophysiologic process has been identified.

\section{Table 1: Past and present classification of idiopathic interstitial pneumonias}

\begin{tabular}{|c|c|c|}
\hline Past & \multicolumn{2}{|c|}{ Present } \\
\hline Histological pattern* & Histological pattern† & $\begin{array}{l}\text { Diagnosis based on } \\
\text { clinical, radiological and } \\
\text { histological findings }\end{array}$ \\
\hline $\begin{array}{l}\text { Usual interstitial } \\
\text { pneumonia }\end{array}$ & $\begin{array}{l}\text { Usual interstitial } \\
\text { pneumonia }\end{array}$ & $\begin{array}{l}\text { Idiopathic pulmonary } \\
\text { fibrosis; also known as } \\
\text { cryptogenic fibrosing } \\
\text { alveolitis }\end{array}$ \\
\hline \multirow[t]{2}{*}{$\begin{array}{l}\text { Nonspecific interstitial } \\
\text { pneumonia }\end{array}$} & $\begin{array}{l}\text { Nonspecific interstitial } \\
\text { pneumonia }\end{array}$ & $\begin{array}{l}\text { Nonspecific interstitial } \\
\text { pneumonia§ }\end{array}$ \\
\hline & Organizing pneumonia & $\begin{array}{l}\text { Cryptogenic organizing } \\
\text { pneumonia } \uparrow\end{array}$ \\
\hline $\begin{array}{l}\text { Acute interstitial } \\
\text { pneumonia }\end{array}$ & Diffuse alveolar damage & $\begin{array}{l}\text { Acute interstitial } \\
\text { pneumonia }\end{array}$ \\
\hline $\begin{array}{l}\text { Respiratory bronchiolitis- } \\
\text { associated interstitial lung } \\
\text { disease }\end{array}$ & Respiratory bronchiolitis & $\begin{array}{l}\text { Respiratory bronchiolitis- } \\
\text { associated interstitial lung } \\
\text { disease }\end{array}$ \\
\hline \multirow[t]{2}{*}{$\begin{array}{l}\text { Desquamative interstitial } \\
\text { pneumonia }\end{array}$} & $\begin{array}{l}\text { Desquamative interstitial } \\
\text { pneumonia }\end{array}$ & $\begin{array}{l}\text { Desquamative interstitial } \\
\text { pneumonia }\end{array}$ \\
\hline & $\begin{array}{l}\text { Lymphoid interstitial } \\
\text { pneumonia }\end{array}$ & $\begin{array}{l}\text { Lymphoid interstitial } \\
\text { pneumonia }\end{array}$ \\
\hline
\end{tabular}

${ }^{*}$ Classification by Katzenstein and Myers' ${ }^{1}$ was based on histological findings and not clinical characteristics. Katzenstein and Myers did not include organizing pneumonia or lymphoid interstitial pneumonia in this classification.

†Histological pattern that corresponds to the clinical disorder indicated on the right. ${ }^{4}$

‡Clinical disorder that corresponds to the histological pattern indicated on the left.

§Provisional nomenclature subject to further classification. ${ }^{4}$

I Also known as bronchiolitis obliterans organizing pneumonia.

\section{Pathology}

The pathological criteria for the diagnosis of IPF have undergone substantial changes. Under the current classification IPF refers to the clinical disease, and the typical histological features of IPF are called usual interstitial pneumonia. ${ }^{1-4}$ Usual interstitial pneumonia is characterized by temporal heterogeneity and the presence of fibroblast foci (Fig. 1D $)^{1-4,9-12}$ and may be seen with other conditions such as pulmonary fibrosis associated with asbestosis, collagen vascular disease, chronic drug toxicity, chronic hypersensitivity pneumonitis and familial idiopathic pulmonary fibrosis, as well as in rare conditions such as Hermansky-Pudlak syndrome. ${ }^{3}$ However, these conditions are usually easily distinguished from IPF on clinical grounds.

The histological lesions of IPF are best seen with lowpower microscopy, which demonstrates areas of normalappearing lung tissue interspersed with interstitial fibrosis, inflammatory cells and distortion of the normal lung architecture to form honeycomb cysts and fibroblast foci (Fig. 1). ${ }^{1-4,9-12}$ Honeycomb cysts are enlarged and distorted airspaces resulting from destruction of the normal alveoli. ${ }^{4}$ Fibroblast foci are areas with palisades of fibroblasts and connective tissue located just beneath hyperplastic type 2 pneumocytes. ${ }^{1,4}$ The distribution of pathological changes is subpleural, paraseptal and prominent at the bases (Fig. 1). ${ }^{4,49,50}$

Under the current classification, other idiopathic interstitial pneumonias are termed nonspecific interstitial pneumonia, organizing pneumonia, diffuse alveolar damage, respiratory bronchiolitis, desquamative interstitial pneumonia and lymphoid interstitial pneumonia (Table 1). ${ }^{4}$ Lung diseases associated with these other idiopathic interstitial pneumonia patterns are all responsive to corticosteroid treatment. ${ }^{1-3,6-12}$ The histological findings of some lung biopsies may demonstrate more than 1 disease (e.g., lesions compatible with both nonspecific interstitial pneumonia and usual interstitial pneumonia). The prognosis is determined by the extent of changes compatible with usual interstitial pneumonia., ${ }^{2,9-11}$

\section{Clinical features}

Idiopathic interstitial pneumonias as a group generally present with cough and minimal or no sputum production. The most common clinical presentation of IPF is that of insidious progressive shortness of breath, or dyspnea, being present for at least 3 to 4 months. ${ }^{3,451}$ Cough may be present with or without sputum. ${ }^{34,51}$ On physical examination $25 \%-50 \%$ of patients with IPF have evidence of clubbing. ${ }^{3-5,51}$ The presence of clubbing is helpful in suggesting a diagnosis of 
IPF, but it is also observed in patients who have pulmonary fibrosis associated with rheumatoid arthritis, asbestosis or fibrosing nonspecific interstitial pneumonia. ${ }^{4,51}$ On auscultation, there are fine inspiratory crackles, heard best in mid- to end inspiration. ${ }^{3,451}$ With more severe disease, increased right heart pressure and right ventricular failure may be evident.,52

The clinical diagnostic approach begins with a detailed history, physical examination, radiological imaging, lung function studies, blood tests and tissue analysis. ${ }^{3,451}$ The history should include a detailed occupational history and any exposures to the potential causative agents mentioned earlier. Since the majority of patients with IPF are over 60 years, a patient younger than 50 years with the clinical and radiological features of IPF may well have another disorder. Similarly, since IPF is confined to the lungs, the presence of systemic complaints suggests an alternate diagnosis or a concomitant illness such as an infection.

\section{Investigations}

\section{Imaging}

A plain film of the lungs usually demonstrates reticular abnormalities and honeycombing, especially at the bases., ${ }^{3,49-51,53}$ These findings, however, are not specific to IPF. Highresolution CT scanning has greatly improved the ability to visualize and characterize the abnormalities in IPF., 3,6-8,13,49,50,53 Changes felt to be secondary to IPF on scanning include reticular densities, traction bronchiectasis, honeycomb cysts, septal thickening and a subpleural distribution of the abnormalities described earlier (Fig. 2). ${ }^{3,89,49,50,53}$ Again, these changes are most prominently seen at the bases. ${ }^{3,49,50,53}$ The presence of ground-glass appearance on high resolution $\mathrm{CT}$ is not characteristic of IPF., ${ }^{3,4,50,53} \mathrm{IPF}$ can be correctly diagnosed by CT scan in up to $80 \%$ of patients with biopsy-proven IPF. . $^{5,55}$
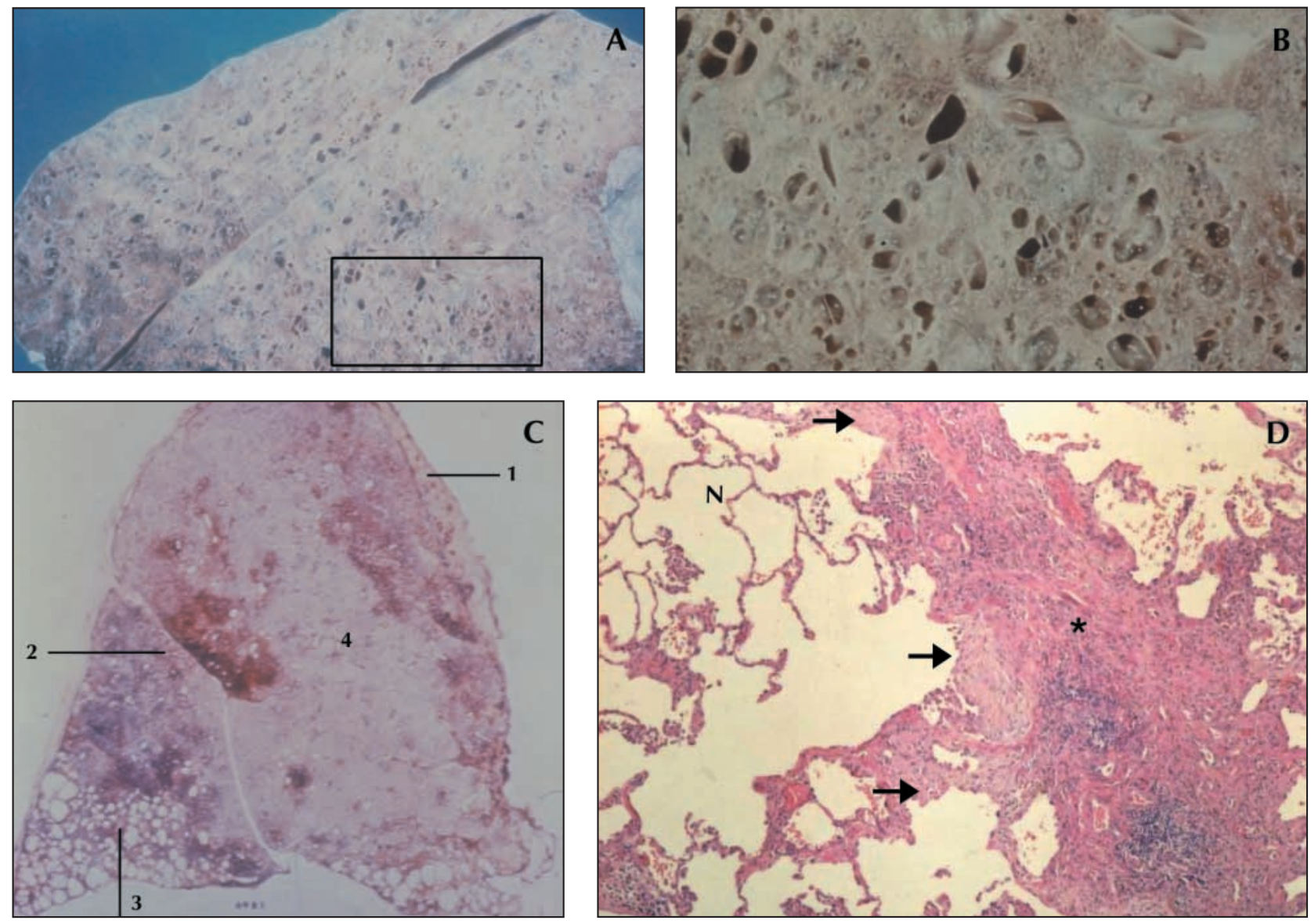

Fig. 1: Gross and histological changes of idiopathic pulmonary fibrosis. A: Section of a lung removed at autopsy from a patient with IPF demonstrates honeycomb cysts. B: Enlargement of the area identified in 1A at a higher magnification shows the cystic lesions of honeycomb cysts. C: Whole-lung thin section highlights the subpleural and basal predominance of pathological changes of IPF, with less involvement of the lung tissue in the more central zones. The pleura is identified by (1); (2) is the preferred site of a diagnostic biopsy, at an interface between honeycomb lung and less involved lung tissue; (3) is an area of honeycomb lung; (4) is a more central area of the lung with minimal changes and appears grossly normal. D: Temporal heterogeneity of histological findings in a single biopsy observed to contain normal lung tissue $(\mathrm{N})$, fibroblast foci (arrows) and interstitial fibrosis $(*)$. Magnification is $\times 40$. 
MRI scanning ${ }^{56}$ and positron emission tomography ${ }^{57}$ are currently under investigation for their accuracy in diagnosing IPF. Lung scanning with gallium, indium and technetium are of little value in diagnosing or following the progress of IPF. ${ }^{3}$

\section{Pulmonary function tests}

Pulmonary function tests demonstrate the severity of disease and may explain the impact on function and exercise limitation. ${ }^{58}$ Pulmonary function studies have shown restrictive lung volumes and capacities, proportionately normal or supernormal flow relative to the lung volumes and a decrease in the carbon monoxide transfer factor. ${ }^{6-8,58}$ There may be hypoxemia with a widened alveolar-arterial oxygen gradient that increases with exercise. ${ }^{58}$ Gas transfer and desaturation on exercise are well correlated with the extent of disease on high-resolution CT ${ }^{6-8,58}$ To follow disease progression, serial measurements of vital capacity and forced vital capacity may be helpful and are noninvasive and inexpensive. ${ }^{6-8}$

\section{Blood tests}

Since IPF is isolated to the lung and by definition has no associated systemic disease, results of blood tests are generally normal. However, some people may have an elevated neutrophil count caused by a concomitant infection. ${ }^{3} \mathrm{Hy}-$ pergammaglobulinemia is seen in some IPF patients; ${ }^{59,60} \mathrm{el}-$ evated rheumatoid factor and antinuclear antibody titres are seen in about $40 \%$ of patients with IPF. 3,4,59,60

\section{Tissue diagnosis}

Bronchoalveolar lavage is an excellent research tool, ${ }^{37}$ but it does not help in diagnosis or in following patients with IPF for either their response to therapy or the pro-

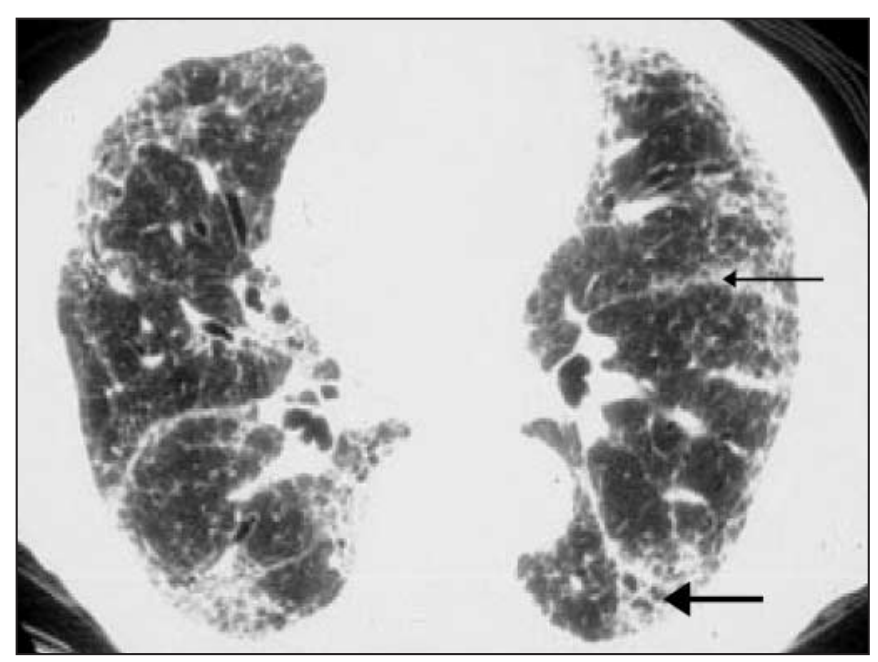

Fig. 2: Radiological changes of IPF on high-resolution CT. Subpleural fibrosis, honeycomb cysts, traction bronchiectasis (thick arrow) and paraseptal fibrosis (thin arrow) are apparent. Relatively minor changes are seen in the central portion of the lung. gression of disease. ${ }^{61,62}$ Because the diagnosis of usual interstitial pneumonia requires a spectrum of histological changes per high-power field, transbronchial biopsy, which provides a very small sample, has limited use as a diagnostic tool. However, bronchoalveolar lavage and transbronchial biopsy can help rule out other causes of pulmonary interstitial infiltrates such as sarcoidosis, hypersensitivity pneumonitis, malignant disease or infection..$^{63}$

Surgical lung biopsy remains the "gold standard" for diagnosis. It is, however, by no means always definitive: the size of specimens, sites of biopsy used, expertise of pathologists and interobserver differences among pathologists are factors that may preclude a conclusive diagnosis. ${ }^{1-4,9-12}$ The site of the biopsy should be chosen on the basis of highresolution CT findings ${ }^{9,35,37,64}$ and ideally be at the interface of involved and less involved lung tissue in order for the biopsy to show the pathological process at an active and recognizable stage. ${ }^{9}$ A biopsy of more than 1 site in the lung is also helpful in diagnosis of both IPF and other interstitial lung diseases. ${ }^{8,64}$ Indications for a surgical lung biopsy suggested by the American Thoracic Society and European Respiratory Society ${ }^{4}$ and by Raghu and colleagues ${ }^{55}$ are listed in Box 1 .

When patients have systemic complaints, a lung biopsy is suggested to rule out other causes of interstitial lung disease. ${ }^{4,55}$ If a radiological feature is not characteristic of IPF (e.g., if it is not subpleural, paraseptal or predominant at the bases), then a lung biopsy is indicated. ${ }^{4,55}$ The decision for a surgical lung biopsy has to be carefully considered, as in one series of biopsies, 10 of 60 patients with IPF who had received an "uncertain diagnosis" or were experiencing a "rapid decline" died within 1 month of the biopsy. ${ }^{65}$ No specific or consistent clinical feature distinguished patients with a poor prognosis after biopsy from the others. In the absence of a surgical lung biopsy the presence of 4 major and 3 of 4 minor diagnostic criteria assures the likelihood of a correct diagnosis of IPF (Box 2). ${ }^{4,52,53,66}$

Box 1: Suggested indications for surgical biopsy in patients with diffuse interstitial lung disease $e^{4,55}$

- Unclear diagnosis

- Age $<50$ yr

- Systemic complaints

- Radiological features atypical of idiopathic pulmonary fibrosis

- Rapid progression of disease

- Normal chest radiograph

- Recurrent pneumothorax

- Benefit of correct diagnosis outweighs the risk of surgery

- Detection of a fibrotic process related to an exposure that may be important for compensation purposes for the patient 


\section{Management}

The management of IPF requires a methodical approach, regular evaluations and implementation of pharmacological and nonpharmacological modalities. Pharmacotherapy consists of immunosuppressive agents or antifibrotic agents; many drug therapies have both functions.

\section{Immunosuppressive therapy}

Currently no single or combined immunosuppressive agent has been found to improve survival of patients with IPF. ${ }^{4,30-32}$ Although corticosteroids have been standard therapy for years, ${ }^{30,32}$ no evidence of benefit in survival has been established. The use of corticosteroids is also associated with side effects and complications. ${ }^{30,32,67}$ Earlier reports demonstrating improvement with corticosteroids ${ }^{3,51}$ are difficult to interpret because, given the confusion of diagnostic criteria, some patients who responded may have had another disorder.,9-12,68 For example, the re-examination of surgical lung biopsies in one centre yielded a number of cases that would now be called nonspecific interstitial pneumonia, which is steroid responsive. ${ }^{68}$ Despite the lack of evidence, a common therapy currently used for IPF is corticosteroids in conjunction with azathioprine..$^{30-32,69}$ The combination of prednisone $(20 \mathrm{mg} / \mathrm{d})$ and azathioprine ( $3 \mathrm{mg} / \mathrm{kg}$ daily but not to exceed $200 \mathrm{mg} / \mathrm{d}$ ) was reported to tend to stabilize lung function, but no comment on mortality rates could be made since the duration of the study was only 1 year. ${ }^{69}$ Before starting the combined therapy it may be wise to determine if the patient has latent tuberculosis by doing a tuberculin skin test. ${ }^{70}$ Patients taking azathioprine should be monitored for hepatotoxic effects, renal dysfunction and bone marrow suppression. ${ }^{69}$ Patients taking steroids should be assessed for side effects and complications of chronic corticosteroid use, and osteoporosis prevention with vitamin $\mathrm{D}$ and calcium supplementation and bisphosphonates should be undertaken..$^{22,67}$ Corticosteroids combined with cyclophosphamide have been less successful in stabilizing lung function or affecting mortality. ${ }^{31}$

\section{Antifibrotic therapy}

A number of agents that interfere with collagen synthesis have been tested in clinical trials: pirfenidone, interferon gamma-1b, interferon beta-1a, colchicine and penicillamine. ${ }^{71}$ Many of the trials used small numbers of patients, and although some patients demonstrated improved or stabilized lung function, no antifibrotic agent has had any effect on mortality.

Pirfenidone is a pyridone molecule that inhibits connective tissue synthesis in an animal model of pulmonary fibrosis. ${ }^{72}$ In one study, 54 patients who had failed other therapeutic measures were given pirfenidone on a compassionate basis for 1 year. ${ }^{73}$ From the time of entry to followup at 24 months, there was no deterioration in the percent of predicted forced vital capacity, total lung capacity, gas transfer, oxygen saturation and litres of supplemental oxygen used. A study from Japan using pirfenidone drew a similar conclusion. ${ }^{74}$

Interferon gamma-1b is a glycoprotein found to inhibit collagen synthesis by fibroblasts and in animal models of pulmonary fibrosis. ${ }^{75}$ In a randomized trial 9 patients received interferon gamma- $1 \mathrm{~b}(200 \mu \mathrm{g} / \mathrm{d} 3$ times per week) plus prednisolone (7.5 mg orally per day) and were compared with 9 patients who received prednisolone ( $7.5 \mathrm{mg}$ orally per day) alone. ${ }^{76}$ All 9 patients receiving interferon gamma-1b plus prednisolone had an improvement in their lung function. A larger, multicentred, double-blind randomized trial evaluating the survival benefit for patients taking interferon gamma$1 \mathrm{~b}$ plus prednisone versus those taking prednisone and placebo revealed that interferon gamma-1b did not affect progression of the disease, lung function or quality of life. ${ }^{77}$ Survival benefits could not be adequately assessed because the duration of the study was 1 year.

Interferon beta-1a has been reported to inhibit proliferation of fibroblasts and collagen synthesis by fibroblasts and also to inhibit collagen lattice contraction. ${ }^{78} \mathrm{~A}$ ran-

Box 2: Major and minor criteria for the diagnosis of idiopathic pulmonary fibrosis in the absence of a surgical lung biopsy*†

\section{Major criteria}

- Exclusion of known causes of interstitial lung disease, such as drug toxicity, exposure to environmental respiratory hazards and the presence of connective tissue disease

- Evidence of restrictive lung disease such as reduced vital capacity, impaired gas exchange with an increased alveolar-arterial oxygen gradient, decrease in partial arterial pressure of oxygen at rest or during exercise, decreased carbon monoxide gas transfer

- High-resolution CT showing bibasilar reticulonodular opacities with minimal or no ground-glass appearance

- A transbronchial biopsy or bronchoalveolar lavage findings that would not support other diagnosis such as sarcoidosis, hypersensitivity pneumonitis, malignant disease, infection, cryptogenic organizing pneumonia or pulmonary alveolar proteinosis

\section{Minor criteria}

- Age > 50 yr

- Insidious onset of dyspnea with no discernible cause

- Duration of symptoms $>3 \mathrm{mo}$

- Bilateral inspiratory crackles

*Diagnosis requires all 4 major criteria and 3 of the 4 minor criteria. †Adapted from reference 3 . 
domized placebo-controlled trial involving 167 patients did not demonstrate that interferon beta-1a was of therapeutic benefit. ${ }^{79}$

Colchicine inhibits fibroblast proliferation and collagen deposition ${ }^{80,81}$ and decreases the expression of plateletderived growth factor-beta, a mesenchymal mitogen..$^{80,81}$ Studies in which colchicine was administered to patients with IPF have failed to demonstrate a survival advantage. . $^{80,81}$

Penicillamine is a chelating agent that suppresses inflammation and collagen deposition. ${ }^{82}$ Small trials investigating the use of penicillamine in patients with IPF have failed to demonstrate clinical efficacy or survival benefits. ${ }^{81}$

Novel antifibrotic treatments are currently being studied (Table 2)..$^{83-89}$

\section{Nonpharmacological treatment}

In a study by Lok, patients with IPF were found to do better when followed in an interstitial lung disease clinic. ${ }^{90}$ In that context, attention to fitness, good nutrition, oxygen supplementation when necessary, treatment of concomitant illness, prevention of morbidity from therapy and early referral for transplantation are all likely to be important in the reduction of morbidity in and management of IPF..$^{90,91}$ Lung transplantation has been shown to improve survival in patients with IPF. ${ }^{92,93}$ In one study a single lung transplantation reduced the risk of death by $75 \%$ (95\% CI $8 \%-86 \%, p=0.03$ ) compared with patients with IPF on the transplant waiting list. ${ }^{92}$ No cases of disease recurrence were reported in the donor lung after transplantation. Since IPF is a progressive disease and no treatment is

\section{Table 2: Examples of anti-inflammatory and antifibrotic agents as potential therapeutic options for the treatment of idiopathic pulmonary fibrosis (IPF)}

\begin{tabular}{|c|c|}
\hline Agent & Comments \\
\hline $\mathrm{N}$-acetylcystine & $\begin{array}{l}\text { Antioxidant agent, may reduce injury in IPF } \\
\text { lungs }^{83}\end{array}$ \\
\hline $\begin{array}{l}\text { CD36 synthetic } \\
\text { peptide }\end{array}$ & $\begin{array}{l}\text { Abrogates the conversion of latent } \\
\text { transforming growth factor-beta } 1 \text { (TGF- } \beta 1 \text { ) } \\
\text { to its active conformation and prevents } \\
\text { inflammation and fibrosis in an animal } \\
\text { model of pulmonary fibrosis }{ }^{84}\end{array}$ \\
\hline Captopril & $\begin{array}{l}\text { Angiotensin-converting-enzyme inhibitor, } \\
\text { decreases cardiac, pulmonary and renal } \\
\text { fibrosis in animal models }{ }^{85}\end{array}$ \\
\hline Decorin & $\begin{array}{l}\text { Antagonizes biological activity of TGF- } \beta \\
\text { and decreases pulmonary fibrosis in an } \\
\text { animal mode }{ }^{86}\end{array}$ \\
\hline $\begin{array}{l}\text { Keratinocyte growth } \\
\text { factor }\end{array}$ & $\begin{array}{l}\text { Epithelial cell mitogen, reduces pulmonary } \\
\text { fibrosis in animal models } s^{87}\end{array}$ \\
\hline Bosentan & $\begin{array}{l}\text { Endothelin- } 1 \text { receptor antagonist, reduces } \\
\text { connective tissue synthesis by fibroblasts } \\
\text { and pulmonary fibrosis in animal models }{ }^{88}\end{array}$ \\
\hline Niacin and taurine & $\begin{array}{l}\text { Protect against injury from reactive oxygen } \\
\text { intermediates and in combination decrease } \\
\text { pulmonary fibrosis }^{89}\end{array}$ \\
\hline
\end{tabular}

known to prolong survival other than lung transplantation, ${ }^{92,93}$ patients should be referred for transplantation assessment soon after diagnosis.

\section{Conclusion}

IPF is a progressive interstitial lung disease with no known cause or effective treatment. Combinations of existing therapies may be found to be effective when studied in future clinical trials. Currently, though, patients with IPF require both a comprehensive approach to management, ideally from specialized clinics, and early referral for transplantation.

This article has been peer reviewed.

From the Respiratory Division, the Vancouver Coastal Health Research Institute (Khalil), and the British Columbia Cancer Agency and the University of British Columbia (O'Connor), Vancouver, BC

Competing interests: None declared.

Contributors: Nasreen Khalil was the principal author and contributed substantially to the analysis and review of the literature and to composing the manuscript. Robert O'Connor contributed equally to the composition of the review article. Both authors gave final approval of the version to be published.

\section{References}

1. Katzenstein AL, Myers JL. Nonspecific interstitial pneumonia and the other idiopathic interstitial pneumonias: classification and diagnostic criteria. Am $\mathcal{F}$ Surg Pathol 2000;24:1-3.

2. Katzenstein AL, Zisman DA, Litzky LA, Nyuyen BT, Kotloff RM. Usual interstitial pneumonia: histologic study of biopsy and explant specimens. Am 7 Surg Pathol 2002;26:1567-77.

3. American Thoracic Society. Idiopathic pulmonary fibrosis: diagnosis and treatment. International consensus statement. Am 7 Respir Crit Care Med 2000;161:646-64.

4. American Thoracic Society. ATS/ERS international consensus classification of idiopathic interstitial pneumonias. Am f Respir Crit Care Med 2002;165:277-304.

5. Epler GR, Colby TV, McCloud TC, Carrington CB, Gaensler EA. Bronchiolitios obliterans organizing pneumonia. N Engl 7 Med 1985;312:152-8.

6. Latsi PI, du Bois RM, Nicholson AG, Colby TV, Bisirtzoglou D, Nikolakopopoulou A, et al. Fibrotic idiopathic interstitial pneumonia: the prognostic value of longitudinal functional trends. Am 7 Respir Crit Care Med 2003; 168:531-7.

7. Collard HR, King TE, Bartelson BB, Vourlekis JS, Schwartz MI, Brown KK Changes in clinical and physiological variables predict survival in idiopathic pulmonary fibrosis. Am 7 Respir Crit Care Med 2003;168:538-42.

8. Flaherty KR, Mumford JA, Murray S, Kazerooni EA, Gross BH, Colby TV, et al. Prognostic implications of physiologic and radiologic changes in idiopathic interstitial pneumonia. Am 7 Respir Crit Care Med 2003;168:543-8.

9. Flaherty KR, Kazerooni EA, Gross BH, Toews GB, Colby TV, Travis WD, et al. Radiological versus histological diagnosis in UIP and NSIP: survival implications. Thorax 2003;58:143-8.

10. Katzenstein AL, Meyers JL. Idiopathic pulmonary fibrosis: clinical relevance of pathological classification. Am Z Respir Crit Care Med 1998;157:1301-15.

11. Flaherty KR, Toews GB, Travis WD, Colby TV, Kazerooni EA, Gross BH, et al. Clinical significance of histological classification of idiopathic interstitial pneumonia. Eur Respir 7 2002;19:275-83.

12. Travis WD, Matsui K, Moss JE, Ferrans VJ. Idiopathic nonspecific interstititial pneumonia: prognostic significance of cellular and fibrosing patterns. Survival comparison with usual interstitial pneumonia and desquamative interstitial pneumonia. Am 7 Surg Pathol 2000;24:19-33.

13. Hansell A, Hollowell J, Nichols T, McNiece R, Strachan D. Use of the General Practice Research Database (GPRD) for respiratory epidemiology: a comparison with the 4th Morbidity Survey in General Practice (MSGP4). Thorax 1999;54:413-9.

14. Coultas D, Zumwalt W, Black W, Sobonya R. The epidemiology of interstitial lung disease. Am 7 Respir Crit Care Med 1994;150:967-72.

15. Baumgartner KB, Samet JM, Stidley CA, Colby TV, Waldron JA. Cigarette smoking: a risk factor for idiopathic pulmonary fibrosis. Am 7 Respir Crit Care Med 1997; 155:242-8

16. Baumgartner KB, Samet JM, Coultas DB, Stidley CA, Hunt WC, Colby TV, et al. Occupational and environmental risk factors for idiopathic pulmonary 
fibrosis: a multicenter case-control study. Collaborating centres. Am 7 Epidemiol 2000;152:307-15.

17. Iwai K, Mori T, Yamada N, Yamaguchi M, Hosoda Y. Idiopathic pulmonary fibrosis: epidemiological approaches to occupational exposure. Am 7 Respir Crit Care Med 1994;150:670-5.

18. Egan JJ, Stewart JP, Hasleton PS, Arrand JR, Carroll KB, Woodcock AA. Epstein-Barr virus replication within pulmonary epithelial cells in cryptogenic fibrosing alveolitis. Thorax 1995;50:1234-9

19. Pinsker KL, Schneyer B, Becker N, Kamholz SL. Usual interstitial pneumonia following Texas A2 influenza infection. Chest 1981;80:123-6.

20. Meliconi R, Andreone P, Fasano L, Galli S, Pacilli A, Miniero R, et al. Incidence of hepatitis $\mathrm{C}$ virus infection in Italian patients with idiopathic pulmonary fibrosis. Thorax 1996;51:315-7.

21. Jakab GJ. Sequential virus infections, bacterial superinfections, and fibrogenesis. Am Rev Respir Dis 1990;142:374-9.

22. Bitterman PB, Rennard SI, Keogh BA, Wewers MD, Adelberg S, Crystal RG. Familial idiopathic pulmonary fibrosis: evidence of lung inflammation in unaffected family members. N Engl 7 Med 1986;314:1343-7.

23. Verleden GM, du Bois RM, Bouros D, Drent M, Millar A, Muller-Quernheim J, et al. Genetic predisposition and pathogenetic mechanisms of interstitial lung diseases of unknown origin. Eur Respir 7 Suppl 2001;32:17s-29s.

24. Selman M, Lin HM, Montano M, Jenkins AL, Estrada A, Lin Z, et al. Surfactant protein $\mathrm{A}$ and $\mathrm{B}$ genetic variants predispose to idiopathic pulmonary fibrosis. Hum Genet 2003;113:542-50.

25. Whyte M, Hubbard R, Meliconi R, Whidborne M, Eaton V, Bingle C, et al. Increased risk of fibrosing alveolitis associated with interleukin-1 receptor antagonist and tumor necrosis factor-alpha gene polymorphisms. Am $\mathcal{F}$ Respir Crit Care Med 2000;162(2 Pt 1):755-8.

26. Zorzetto M, Ferrarotti I, Trisolini R, Agli LL, Scabini R, Novo M, et al. Complement receptor 1 gene polymorphisms are associated with idiopathic pulmonary fibrosis. Am 7 Respir Crit Care Med 2003;168:330-4.

27. Streiter RM. Inflammatory mechanisms are not a minor component of the pathogenesis of idiopathic pulmonary fibrosis. Am J Respir Crit Care Med 2002 165:1206-7.

28. Crystal RG, Bitterman PB, Rennard SI, Hance AJ, Keogh BA. Interstitia lung diseases of unknown cause: disorders characterized by chronic inflammation of the lower respiratory tract. N Engl 7 Med 1994;310:154-66.

29. Selman M, King TE, Pardo A; American Thoracic Society; European Respiratory Society; American College of Chest Physicians. Idiopathic pulmonary fibrosis: prevailing and evolving hypotheses about its pathogenesis and implications for therapy. Ann Internal Med 2001;134:136-51

30. Richeldi L, Davies HR, Ferrara G, Franco F. Corticosteroids for idiopathic pulmonary fibrosis. Cochrane Database Syst Rev 2003;3:CD002880.

31. Davies HR, Richeldi L, Walters EH. Immunomodulary agents for idiopathic pulmonary fibrosis. Cochrane Database Syst Rev 2003;3:CD003134.

32. Flaherty KR, Toews GB, Lynch JP 3rd, Kazerooni EA, Gross BH, Strawderman RL, et al. Steroids in idiopathic pulmonary fibrosis: a prospective assessment of adverse reactions, response to therapy, and survival. Am 7 Med 2001;110:278-82.

33. Xu Y, Hua J, Mui A, O'Connor R, Grotendorst G, Khalil N. Release of biologically active TGF-beta 1 by alveolar epithelial cells results in pulmonary fibrosis. Am 7 Physiol Lung Cell Mol Physiol 2003;285:L527-39.

34. Munger JS, Huang X, Kawakatsu H, Griffiths MJ, Dalton SL, Wu J, et al. The integrin alpha $\mathrm{v}$ beta 6 binds and activates latent TGF-beta 1: a mechanism for regulating pulmonary inflammation and fibrosis. Cell 1999;96:319-28.

35. Majumdar S, Li D, Ansari T, Pantelidis P, Black CM, Gizycki M, et al. Different cytokine profiles in cyptogenic fibrosing alveolitis and fibrosing alveolitis associated with systemic sclerosis: a quantitative study of open lung biopsies. Eur Respir 7 1999;14:251-7.

36. Khalil N, O'Connor R, Flanders K, Unruh H. TGF-beta1, but not TGF-beta 2 or TGF-beta 3, is differentially present in epithelial cells of advanced pulmonary fibrosis: an immunohistochemical study. Am 7 Respir Cell Mol Biol 1996;14:131-8.

37. Khalil N, O'Connor R, Unruh H, Warren P, Kemp A, Bereznay O, et al. Increased production and immunohistochemical localization of transforming growth factor-beta (TGF-beta) in idiopathic pulmonary fibrosis. Am 7 Respir Cell Mol Biol 1991;5:155-162.

38. Khalil N, Parekh TV, O'Connor R, Antman N, Kepron W, Yehaulaeshet T, et al. Regulation of the effects of TGF-beta 1 by activation of latent TGFbeta 1 and differential expression of TGF-beta receptors ( $T$ beta R-I and T beta R-II) in idiopathic pulmonary fibrosis. Thorax 2001;56:907-15.

39. Antoniades HN, Bravo MA, Avila RE, Galanopoulos T, Neville-Gordon J, Maxwell M. Platelet-derived growth factor in idiopathic pulmonary fibrosis. $\mathcal{F}$ Clin Invest 1990;86:1055-64.

40. Pan LH, Ohtani H, Yamauchi K, Nagwa H. Co-expression of TNF-alpha and IL-1 beta in human acute pulmonary fibrotic diseases: an immunohistochemical analysis. Pathol Int 1996; 46:91-9.

41. Nash JR, McLaughlin PJ Butcher D, Corrin B. Expression of tumor necrosis factor-alpha in cryptogenic fibrosing aveolitis. Histopathol 1993;22:343-7.

42. Uh ST, Inoue Y, King TE Jr, Chan ED, Newman LS, Riches DW. Morphometric analysis of insulin-like growth factor-I localization in lung tissues of patients with idiopathic pulmonary fibrosis. Am 7 Respir Crit Care Med 1998; 158:1626-35.
43. Inoue Y, King TE Jr, Barker E, Daniloff E, Newman LS. Basic fibroblast growth factor and its receptors in idiopathic pulmonary fibrosis and lymphangioleiomyomatosis. Am 7 Respir Crit Care Med 2002;166:765-73.

44. Xu YD, Hua J, O'Connor R, Khalil N. Chronic release of active TFG-beta by alveolar epithelial cell (AEC) line, L-2 results in connective tissue (CT) synthesis and conversion of L-2 cells to a fibroblast-like phenotype. Am 7 Respir Crit Care Med 2003;167:A572.

45. Ramos C, Montano M, Garcia-Alvarez J, Ruiz V, Uhal BD, Selman M, et al. Fibroblasts from idiopathic pulmonary fibrosis and normal lungs differ in growth rate, apoptosis, and tissue inhibitor of metalloproteinases expression. Am 7 Respir Cell Mol Biol 2001;24:591-8.

46. Xu YD, Hua J, Chen G, Simon T, Mui A, Khalil N. Alveolar epithelial cells (AEC) of normal rat lung explants transfected with the retrovirus, $\mathrm{pMX}$-Ls223, 225-TGF-beta1 results in connective tissue (CT) synthesis and fibroblast proliferation. Am 7 Respir Crit Care Med. 2003;167:A568.

47. Furuie H, Yamansali H, Suga M, Ando M. Altered accessory cell function of alveolar macrophages: a possible mechanism for induction of Th2 secretory profile in idiopathic pulmonary fibrosis. Eur Respir 7 1997;10:787-94.

48. Suveer S, du Bois R. Autoantibodies in cryptogenic fibrosing alveolitis. Respir Res 2001;2:61-3.

49. Schettino IA, Ab'Saber AM, Vollmer R, Saldiva PH, Carvalho CR, Kairalla RA et al. Accuracy of high resolution CT in assessing idiopathic pulmonary fibrosi histology by objective morphometric index. Pathol Res Pract 2002;198:347-54.

50. Wells AU, Desai SR, Rubens MB, Goh NSL, Cramer D, Nicholson AG, et al. Idiopathic pulmonary fibrosis: a composite physiological index derived from disease extent observed by computed tomography. Am 7 Respir Crit Care Med 2003;167:962-9.

51. Johnston IDA, Prescott RJ, Chalmers JC, Rudd RM. British Thoracic Society study of cryptogenic fibrosing alveolitis: current presentation and initial management. Thorax 1997;52:38-44.

52. Channick RN, Hoch RC, Newhart JW, Johnson FW, Smith CM. Improvement in pulmonary hypertension and hypoxemia during nitric oxide inhalation in a patient with end-stage pulmonary fibrosis. Am J Respir Crit Care Med 1994:149:811-4.

53. Ellis SM, Hansell DM. Idiopathic interstitial pneumonias imaging-pathology correlation. Eur Radiol 2002;12:610-26.

54. Hunninghake GW, Zimerman MB, Scwartz DA, King TE, Lynch J, Hegle $\mathrm{R}$, et al. Utility of a lung biopsy for the diagnosis of idiopathic pulmonary fibrosis. Am 7 Respir Crit Care Med 2001;164:193-6.

55. Raghu G, Mageto YN, Lockhart D, Schmidt RA, Wood DE, Godwin JD. The accuracy of the clinical diagnosis of new-onset idiopathic pulmonary fibrosis and other interstitial lung disease: a prospective study. Chest 1999;116:1168-74.

56. Primack SL, Mayo JR, Hartman TE, Miller RR, Muller NL. MRI of infiltrative disease: comparison with pathologic findings. 7 Comput Assit Tomogr 1994;18:233-8

57. Jones HA, Boobis AR, Hamacher K, Coenen HH, Clark JC. PET imaging of pulmonary fibrosis. 7 Nucl Med 2003;44:483-4

58. Alhamad EH, Lynch JP 3rd, Martinez FJ. Pulmonary function tests in interstitial lung disease: What role do they have? Clin Chest Med 2001;22:715-50.

59. Meliconi R, Bestagno M, Sturani C, Negri C, Galavotti V, Sala C, et al. Autoantibodies to DNA topoisomerism II in cryptogenic fibrosing alveolitis and connective tissue disease. Clin Exp Immunol 1989;76:184-9.

60. Pluss JL, West SG. Idiopathic pulmonary fibrosis associated with high-titer antibodies against ribonucleoprpotein (nRNP): report of 3 cases. $7 \mathrm{Am}$ Ostopath Assoc 1986;86:735-42.

61. Costabel U, Guzman J. Bronchoalveolar lavage in interstitial lung disease. Curr Opin Pulm Med 2001;7:255-61.

62. Veeraraghavan S, Latsi PI, Wells AU, Pantelidis P, Nicholson AG, Colby $\mathrm{TV}$, et al. BAL findings in idiopathic nonspecific interstitial pneumonia and usual interstitial pneumonia. Eur Respir 7 2003;22:239-44.

63. Poletti V, Patelli M, Ferracini R, Simonetti M, Spiga L. Transbronchial lung biopsy in infiltrative lung disease. The importance of the pathologic approach. Sarcoidosis 1988;5:43-50.

64. Flint A, Martinez F, Young ML, Whyte RI, Toews GB, Lynch JP. Influence of sample number and biopsy site on the histologic diagnosis of diffuse lung disease. Ann Thorac Surg 1995;60:1605-8.

65. Utz JP, Ryu JH, Douglas WW, Tazelaar HD, Myers JL, Allen MS, et al High short-term mortality following lung biopsy for usual interstitial pneumonia. Eur Respir 7 2001;17:175-9.

66. Hunninghake GW, Lynch DA, Galvin JR, Gross BH, Muller N, Schwartz $\mathrm{DA}$, et al. Radiological findings are strongly associated with a pathological diagnosis of usual interstitial pneumonia. Chest 2003;124:1215-23.

67. Douglas WM, Samet JM, Coultas DB. Corticosteroids and the treatment of idiopathic pulmonary fibrosis. Chest 1996;110:1058-67.

68. Bjoraker JA, Ryu JH, Edwin MK, Myers JL, Tazelaar HD, Schroeder DR, et al. Prognostic significance of histological subsets in idiopathic pulmonary fibrosis. Am 7 Respir Crit Care Med 1998;157:199-203.

69. Raghu G, Depaso WJ, Cain K, Hammer AP, Wetzel CE, Dreis DF, et al Azathioprine combined with prednisone in the treatment of idiopathic pulmonary fibrosis: a prospective double-blind, randomized, placebo-controlled clinical trial. Am Rev Respir Dis 1991;144:291-6. 
70. Hernandez-Cruz B, Ponce-de-Leon-Rosales S, Sifuentes-Osornio J, Poncede-Leon-Garduno A, Diaz-Jouanen E. Tuberculosis prophylaxis in patients with steroid treatment and systemic rheumatic diseases. A case-control study. Clin Exp Rheumatol 1999;17:81-8.

71. Lasky JA, Ortiz LA. Antifibrotic therapy for the treatment of pulmonary fibrosis. Am 7 Med Sci 2001;322:213-21.

72. Dosanjh A, Ikonen T, Wan B, Morris RE. Pirfenidone: a novel anti-fibrotic agent and progressive chronic allograft rejection. Pulm Pharmacol Ther 2002;15:433-7.

73. Raghu G, Johnson WC, Lockhart D, Mageto Y. Treatment of idiopathic pulmonary fibrosis with a new antifibrotic agent, pirfenidone. Am 7 Respir Crit Care Med 1999;159:1061-9.

74. Nagai S, Hamada K, Shigematsu M, Taniyama M, Yamaauchi S, Izumi T. Open-label compassionate use one-year treatment with pirfenidone to patients with chronic pulmonary fibrosis. Intern Med 2002;41:1118-23.

75. Lortat-Jacob H, Esterre P, Grimaud JA. Interferon-gamma, an anti-fibrotic cytokine which binds to heparan sulfate. Pathol Res Pract 1994;190:920-2 .

76. Ziesche R, Hofbauer E, Wittmann K, Petkov V, Block LH. A preliminary study of long-term treatment with interferon gamma-1b and low dose prednisolone in patients with idiopathic pulmonary fibrosis. N Engl 7 Med 1999;341:1264-9.

77. Raghu G, Brown KK, Bradford WZ, Starko K, Noble PW, Schwartz DA, et al. A placebo-controlled trial of interferon gamma-1b in patients with idiopathic pulmonary fibrosis. N Engl 7 Med 2004;350:125-33.

78. Cornelissen AM, Von den Hoff JW, Malta JC, Kuijpers-Jagtman AM. Effects of interferons on proliferation and collagen synthesis of rat palatal wound fibroblasts. Arch Oral Biol 1999;44:541-7.

79. Raghu G, Bozic CR, Brown K. Feasibility of a trial of interferon beta-1a in the treatment pulmonary fibrosis [abstract]. Am 7 Respir Crit Care Med 2001; 163:A707.

80. Douglas WW, Ryu JH, Schroeder DR. Idiopathic pulmonary fibrosis. Impact of oxygen and colchicines, prednisone, or no therapy on survival. Am 7 Respir Crit Care Med 2000;161:1172-8.

81. Selman M, Carrillo G, Salas J, Padilla RP, Perez-Chavira R, Sansores R, et al. Colchicine, D-penicillamine, and prednisone in the treatment of idiopathic pulmonary fibrosis: a controlled clinical trial. Chest 1998;114:507-12.

82. Geismar LS, Hennessey S, Reiser KM, Last JA. D-penicillamine prevents collagen accumulation in lungs of rats given bleomycin. Chest 1986;89:153S-4S.

83. Behr J, Maier K, Degenkolb B, Krombach F, Vogelmeier C. Antioxidant and clinical effects of high-dose $N$-acetylcysteine in fibrosing alveolitis. Adjunctive therapy to maintenance immunosuppression. Am 7 Respir Crit Care Med 1997;156:1897-901.

84. Yehualaeshet T, O'Connor R, Beleiter A, Murphy-Ullrich JE, Silverstein R, Khalil N. Administration of a synthetic peptide of the CD36 receptor reduces bleomycin-induced pulmonary inflammation and fibrosis. Am 7 Respir Cell Mol Biol 2000;23:204-12.

85. Molteni A, Ward WF, Ts'ao CH, Solliday NH, Dunnne M. Monocrotalineinduced pulmonary fibrosis in rats: amelioration by captopril and penicillamine. Proc Soc Exp Biol Med 1985;180:112-20.

86. Kolb M, Margetts PJ, Sime PJ, Gauldie J. Proteoglycans decorin and biglycan differentially modulate TGF-beta-mediated fibrotic responses in the lung. Am 7 Physiol Lung Cell Mol Physiol 2001;280:L1327-34.

87. Sugahara K, Iyama K, Kuroda MJ, Sano K. Double intratracheal instillation of keratinocyte growth factor prevents bleomycin-induced lung fibrosis in rats. F Patbol 1998;186:90-8.

88. Park SH, Saleb D, Giad A, Michel RP. Increased endothelin-1 in bleomycininduced pulmonary fibrosis and the effects of an endothelin receptor antagonist. Am 7 Respir Crit Care Med 1997;156:600-8.

89. Gurujeyalakshmi G, Wang Y, Giri SN. Taurine and niacin block lung injury and fibrosis by down-regulating bleomycin-induced activation of transcription nuclear factor-kappa B in mice. 7 Pharmacol Exp Ther 2000;293:82-90.

90. Lok SS. Interstitial disease clinics for the management of idiopathic pulmonary fibrosis: a potential advantage to patients. 7 Heart Lung Transplant 1999;18:884-90.

91. Snell GI, Walters EH, Kotsimbos TC, Williams TJ. Idiopathic pulmonary fibrosis: in need of focused and systematic management. Med F Aust 2001;174:137-40.

92. Meyers BF, Lynch JP, Turlock EP, Guthrie T, Cooper JD, Patterson GA. Single versus bilateral lung transplantation for idiopathic pulmonary fibrosis: a ten-year institutional experience. 7 Thorac Cardiovasc Surg 2000;120:99-107.

93. Thabut G, Mal H, Castier Y, Groussard O, Brugiere O, Marrash-Chahla R, et al. Survival benefit of lung transplantation for patients with idiopathic pulmonary fibrosis. 7 Thoracic Cardiovasc Surg 2003;126:469-75.

Correspondence to: Dr. Nasreen Khalil, Associate Professor of Medicine, Jack Bell Research Centre, 2660 Oak St., Vancouver BC V6H 3Z6; fax 604 875-4497; nkhalil@interchange.ubc.ca

\section{Holiday Review 2004}

\section{Call for Papers}

We're looking for creative contributions for CMAJ's Holiday Review 2004. Humour, personal reflections, history of medicine, off-beat scientific papers and postcards from the edge of medicine are welcome.

Send your offering to the Managing Editor, Josephine Sciortino (800 663-7336 x2366; josephine.sciortino@cma.ca). Articles should be no longer than 1200 words, and photographs or illustrations are encouraged.

The deadline for submissions is September 13, 2004.

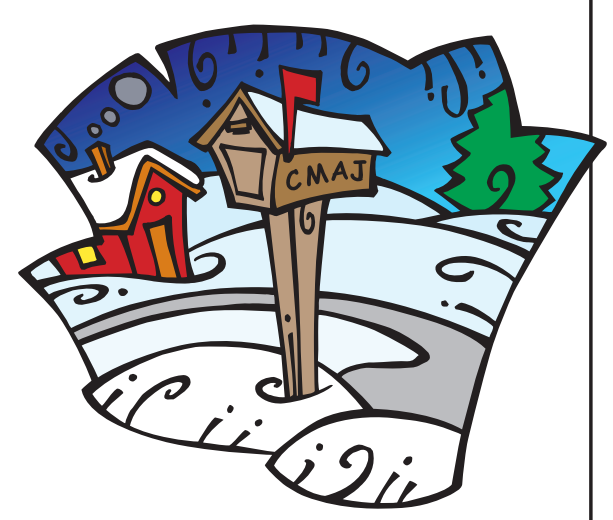

